\title{
Muséologies
}

Les cahiers d'études supérieures

muséologies

\section{Cultural Commotion at the Toronto Carrying Place Trail}

\section{Diane Boyer}

Volume 4, numéro 2, printemps 2010

URI : https://id.erudit.org/iderudit/1033541ar

DOI : https://doi.org/10.7202/1033541ar

Aller au sommaire du numéro

Éditeur(s)

Association Québécoise de Promotion des Recherches Étudiantes en Muséologie (AQPREM)

ISSN

1718-5181 (imprimé)

1929-7815 (numérique)

Découvrir la revue

Citer cet article

Boyer, D. (2010). Cultural Commotion at the Toronto Carrying Place Trail. Muséologies, 4(2), 88-111. https://doi.org/10.7202/1033541ar

\section{Résumé de l'article}

Constatant que l'interprétation officielle d'un site historique naturel, soit le Toronto Carrying Place Trail, ne tient pas compte de son évolution après les $\mathrm{XVII}^{\mathrm{e}}$ et XVIII ${ }^{\mathrm{e}}$ siècles, Diane Boyer propose une réflexion sur les possibilités d'y rattacher une part d'histoire plus récente, marquée notamment par l'industrialisation et l'immigration. Pour ce faire, l'auteure réfléchit aux possibilités qu'offre la nouvelle muséologie, en particulier l'approche communautaire et inclusive de Georges-Henri Rivière, dans l'actualisation et l'appropriation d'un lieu en mutation.
Ce document est protégé par la loi sur le droit d'auteur. L'utilisation des services d'Érudit (y compris la reproduction) est assujettie à sa politique d'utilisation que vous pouvez consulter en ligne.

https://apropos.erudit.org/fr/usagers/politique-dutilisation/ 
Diane Boyer is a Fine Arts graduate of York University and is currently pursuing a master's degree in Museum Studies at the University of Toronto. She has worked for many years in community and urban neighbourhood economic development, and is on an educational leave of absence from her position in the development office of the Art Gallery of Ontario. DIANE.BOYER@UTORONTO.CA 

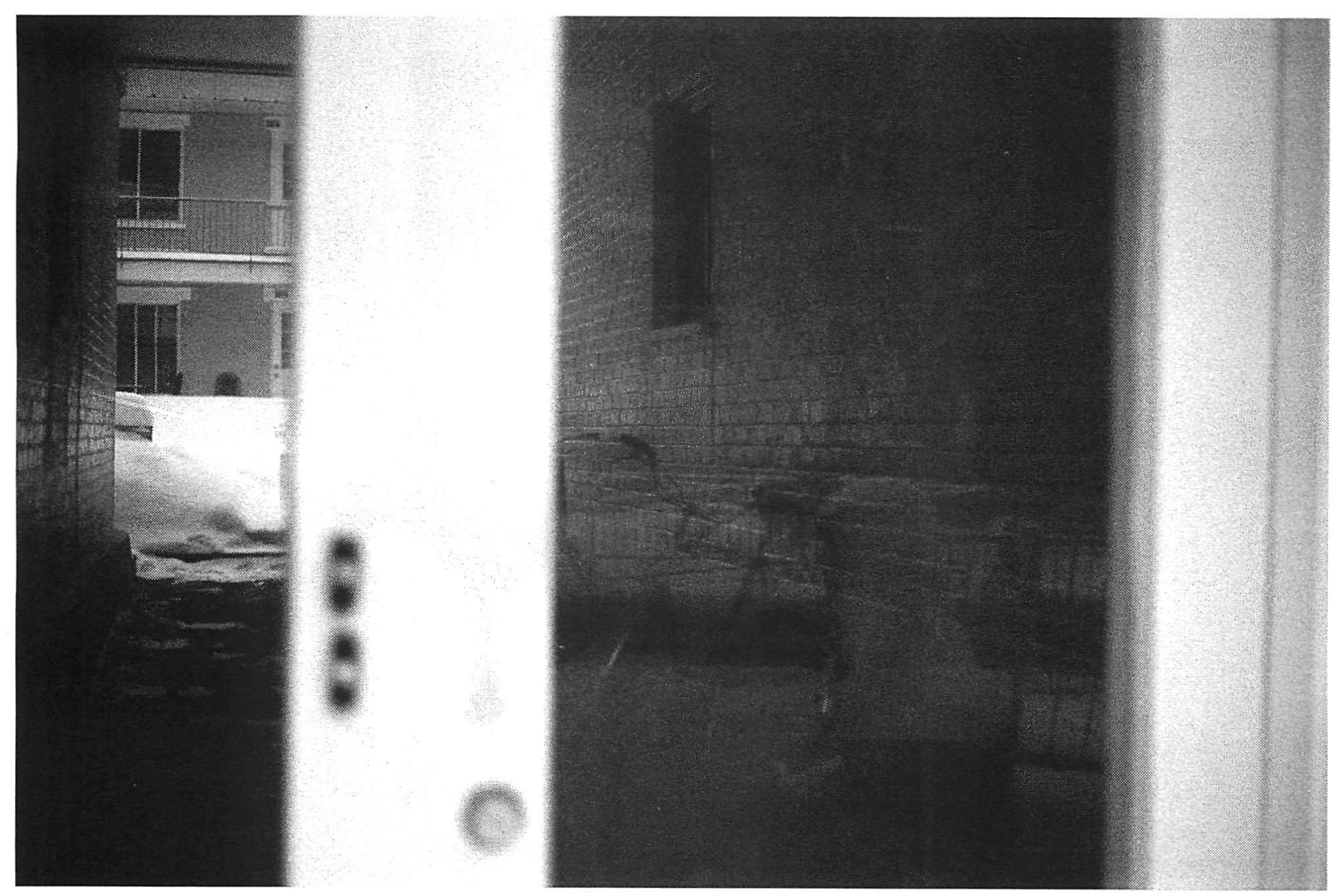


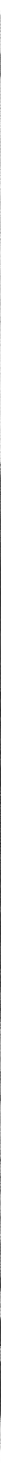

Recreational boating

in the Humber River, c. 1913.

Image courtesy of Heritage York 
Constatant que l'interprétation officielle d'un site historique naturel, soit le Toronto Carrying Place Trail, ne tient pas compte de son évolution après les XVII ${ }^{\mathrm{e}}$ et XVIII ${ }^{\mathrm{e}}$ siècles, Diane Boyer propose une réflexion sur les possibilités d'y rattacher une part d'histoire plus récente, marquée notamment par l'industrialisation et l'immigration. Pour ce faire, l'auteure réfléchit aux possibilités qu'offre la nouvelle muséologie, en particulier l'approche communautaire et inclusive de Georges-Henri Rivière, dans l'actualisation et l'appropriation d'un lieu en mutation. 


\section{Prologue}

\section{Commotion at River's Edge}

Late in 2008, while walking down along an undeveloped stretch of the Humber River in Toronto, I stumbled upon an overgrown historic plaque that marked the location where Jean-Baptiste Rousseaux had operated a trading post at the foot of the Toronto Carrying Place Trail in the 1790s. Rousseaux and his father had run the business from the spot for many years, taking advantage of the active fur trade on the trail during the summer months. I learned from the plaque that Rousseaux was an early example of a multivalent and multilingual Toronto immigrant. He traded with anyone and everyone, ran multiple businesses in the Niagara region, acted as pilot for Simcoe's arrival on the Great Lakes, married a woman who was a ward of the great Mohawk chief Joseph Brant, and died in the War of 1812 serving with British forces at Fort George, near Niagara.

The plaque was in a sorry state of neglect when I first saw it, hemmed in by noisy expressway ramps and obscured by brush from the nearby unpaved public access; its paint was peeling, tall grass and sumac grew all around it, and it looked to be completely forgotten. Yet, it still had the power, for those affected by such things, to convey that deep sense of "remove" that enables a person to picture "being there" in the 1700 s. One could imagine standing at the sandy shallows of the river, and looking back up the hill to see travelers and fur traders complete their long sojourn down the hilly Trail. Most of the 46-kilometre trail has been built over now, but a portion of it is still walkable along Riverside Drive, at the precipice overlooking the mouth of the river into Lake Ontario. It was along this trail that Robert de la Salle, Étienne Brûlé, and others are said to have traveled in their explorations in the $1600 \mathrm{~s}$.

A year later, in 2009, Rousseaux's plaque has been moved up the hill, the dirt landing has been paved and white lines have been painted on it, indicating places where minivans and SUVs can now park and dislodge kayakers and other modern-day wellequipped visitors. The sumac has been cut back and the halfsubmerged concrete blocks, which had formerly made up the 
impromptu "dock," have been cleaned up. A smart new interpretation of the historic Humber Valley is being installed. The river's edge has been opened up, and a kind of gentrified group of new enthusiasts is replacing the traveling ghosts evoked by the old plaque. New paved paths lead from Rousseaux's landing all the way down to the shore of Lake Ontario, following dark and thrilling routes beneath the expressways, and completing a semi-circular bike path across the Humber Bay footbridge.

"I wish they'd cleaned it up more," said a woman standing in the perfect new parking lot. I couldn't help but laugh. I was mentally comparing the clean-cut appearance the City had created to Rousseaux's rough-and-ready entrepreneurship. I was thinking of the homeless guys whose makeshift fishing stools used to sit by the river's edge before the asphalt arrived, and I wondered where they were fishing now. The river kept moving, the same as ever, and a kayaker paddled by. I sensed a commotion brewing between the old use and the new. I myself had driven down there-not arrived on foot.After taking a few pictures, I got back in my car and left.

\section{Cultural commotion} and the "valueless object"

A "valueless object," according to French museologist Jean-Yves Veillard, is one that has not yet acquired any historic or financial value, but whose recognition is pending. ${ }^{1} \mathrm{He}$ was speaking of the objects that might appear in an ecomuseum, a kind of "museum of collective memory" that was conceived in the social and political activism of 1960 s France.

Veillard's example was an ordinary cottage cheese container, like one of thousands that might be found in a recycling bin, but which describes, without any pretence, the daily lives of ordinary, contemporary people. These days, the affix "eco-" implies a "green" philosophy, but the ecomuseum concept expands ecology to its egalitarian outer limit, encompassing not just the flora and fauna of a given geography, but all the activities and industries of people's lives within it-ephemeral, commercial, historical, even mythical. The ecomuseum manifests an area's cultural commotion-the complicated interplay between a natural landscape
VEILLARD, Jean-Yves. "The Valueless Object." Museum, vol. 37, no. 4, 1985. p. 191-193. 
and the vernacular architecture people continuously erect on it. Cultural commotion asks for radical interpretations of geography. It demarcates a "place" - or a network of places-that both anchors and liberates a population, empowering people to tell a personal version of their own history. One person's valueless object has a place in another person's ecomuseum.

Until 1998, when the city of Toronto amalgamated with its outer boroughs, the Humber River represented the meandering western limit of the old town. The Humber was designated a heritage river in 1980, and has been a busy site of industry, trade, and recreation for hundreds of years. Rambling along the spine of the river's valley-the hog's back-the Toronto Carrying Place Trail zigzagged down from the Holland River all the way to Lake Ontario. Below the Holland, the Humber was unnavigable, but the Carrying Place Trail provided a reliable, though arduous, overland route for fur traders and other travelers.

The river and its companion trail are the two "deep structures" of the site-one natural and one man-made. The "commotion" of each is still evident in the area's constant migrations of people, transfers of goods, and rhythms of settlement, recreation, and industry. After visiting the new parking lot at Rousseaux's landing, and seeing the conventional new interpretive changes underway, I wondered how an ecomuseum model might better harness the energies of the site, and release the cultural commotion pent up there. The new historic plaques and memorials being installed along the banks of the river seemed oblivious to the deep geographic structures of the valley, and mostly irrelevant to the lives of the people living in the area now. With minimal interest in the stories available from the local community, the new interpretation asserts a top-down emphasis on early French explorers, aristocrats, and military figures, ignoring alternate layers of history that offer more pluralistic contemporary significance.

\section{The ecomuseum}

\section{and the local voice}

Early proponents of the ecomuseum sought to develop a humanized form of museology that observed the contributions and 
desires of the local inhabitants of a given area from their own points of view. The first ecomuseum experiments demanded a democratization of museum collections and interpretation, a "new museology," as it was later termed, that would transform the ways museums responded to the societies around them, and detonate what was seen as a monolithic, elitist museum establishment. The ecomuseum as a term and an entity found its first footings in the thinking of Georges-Henri Rivière and his work at France's Regional National Parks. Rivière famously called the ecomuseum a "mirror" in which a local community could study itself, a radical alternative to a traditional museology structured on the study of "others." The 1970s socialist ideas, with their focus on the history of the "common man," ignited widespread interest in the ecomuseum's emphasis on overlooked sites and disenfranchised communities.

Although some ecomuseums have been situated in urban centres, an ecomuseum is often defined by rural geographic features, just as the Humber River once defined the boundary of the city. As a concept, the ecomuseum can be defined in various ways, but it will generally encompass four spheres of activity: remembrance or memory, awareness of the environment, cooperative management by both local inhabitants and outside experts, and artistic expression which might include artists' retreats or creative projects linked to local interests or industries. ${ }^{2}$ Other components have more recently been proposed to meet sustainability needs, such as a local responsibility for fundraising, ${ }^{3}$ but the central concerns of preserving collective memory, engaging and empowering the local population, and keeping projects on a human scale are common to all.

\section{A "sense of place"}

Because it comprises an environment in the totality of its lived experience, including all natural attributes and all material and immaterial culture within a specific area, the ecomuseum is best understood as a "sense of place." The ecomuseum creates a sphere of enquiry which treats "theories and ideas as museum objects, and museum objects as tangible ideas." ${ }^{5}$ The tensile area between an "object" and our thinking about it creates a
2

POULOT, Dominique. "Identity as Self-discovery: The Ecomuseum in France." In. SHERMAN, Daniel and Irit ROGOFF (eds.). Museum Culture: Histories, Discourses, Spectacles. Minneapolis: University of Minnesota Press, 2005, p. 72.

3 RIVARD, René. "Ecomuseums in Quebec." Museum International, vol. 53, no. 4,2001, p. 21.

4

See DAVIS, Peter. Ecomuseums: A Sense of Place. New York: Leicester University Press, 1999. p. 3-23. $\mathbf{5}$ RIVIERE, Georges-Henri, cited in POULOT, "Identity as Selfdiscovery...," op. cit., p. 78. 
6

Common Ground. Local

Distinctiveness. <http://www.

england-inparticular.info/cg/

distinctiveness/d-index.html>

7

RIVARD, "Ecomuseums in Quebec,"

op. cit., p. 22.

8

UPTON, Dell. "The Power of Things: Recent Studies in American Vernacular Architecture." American Quarterly, vol. 35, no. 3. 1983, p. 269. 9

RELPH, Edward. "A Pragmatic Sense of Place." In VANCLAY, Frank, Matthew HICGINS, and Adam BLACKSHAW. Making Sense of Place. Canberra: Australian National Museum, 2008, p. 311. 10

RELPH, Edward. Place and

Placelessness. London: Pion, 1976, p. 3. sense of significance-a sense of place and attachment. At times, these nodes of significance will triangulate on a particular landmark-a building or a natural feature-around which a local community will collectively fix special meaning.These "cultural touchstones" - a term used by ecomuseum proponents Common Ground in the UK-generate algorithms of identity that are difficult to specify or analyze, but which own a distinctiveness that individuals in the community instantly understand:

Distinctiveness is about particularity, it is rehearsed in the buildings and land shapes, the brooks and birds, trees and cheeses, places of worship and pieces of literature. It is about continuing history and nature jostling with each other, layers and fragments-old and new. The ephemeral and invisible are important too: customs, dialects, celebrations, names, recipes, spoken history, myths, legends and symbols. ${ }^{6}$

The definitive qualities revealed in a "sense of place" defy precise description, but the fabric of place has some distinctive textures. People tend to give places names,' while mere spaces (the spaces between places) remain nameless and not on the map. Naming is an important mechanism for taking ownership, or feeling attachment. Undercurrents of cultural or social change can be tracked by observing changes in the names of things. ${ }^{8}$

Among cultural geographers, a "place" is a territory of significance, distinguished from other areas by its distinctive environmental qualities, its name, its stories, and the shared memories and experiences people connect to it. ${ }^{9}$ We remember places in personal and subjective terms-the smell of the plants or trees in a certain region, the quality of the light, the sound of people's accents, the distance walked from point $A$ to point B. Places are active nodes on a live network, linking flows of goods and people to other places. ${ }^{10}$

A place can also be recognized by its oppositional phenomenon, "placelessness." Placelessness is a sort of non-place where elements are so empty, or the landscape so standardized and replicable, that "here" could be "anywhere." Placelessness is a force of desertification that compels small towns to demolish antique main streets and substitute shopping malls. Placelessness prefers the low maintenance of the mass produced, and the neat 
appearance of the homogenized, but it can also be chaotic-no sense of place can coalesce in chaos. A placeless geography offers only a shallowness of experience, and a "cauterizing of interpersonal relations." ${ }^{\text {"1 }}$ Placelessness prefers to install the same history for everyone, everywhere, and disdains local character.

\section{A Humber Valley Ecomuseum}

After many years of living and working in the area adjacent to the Humber Valley, I was intrigued by the possibilities an ecomuseum model would offer the valley and its fascinating history, particularly a reappropriation of heritage by the current residents. Spurred by the shortcomings I saw in the recent reinterpretation, I was searching for an inclusive, locally directed form of heritage that could connect the area's various neighbourhoods, and foster a sense of place in the district.

The Toronto Carrying Place Trail was actively used during the years of the fur trade in the $17^{\text {th }}$ and $18^{\text {th }}$ centuries before Yonge Street was built (in 1795). The lower valley has a large natural outcropping that overlooks the river and was occupied by First Nations for centuries before European contact. Wars and plagues decimated the original Huron-Petun population, and by the 1660 s a Seneca fortified town named Teiaiagon occupied the strategic promontory, with a reported population of about 5000 individuals. The town was either destroyed or abandoned in the $1680 \mathrm{~s}$, and the area was later thinly occupied by French military forces. Over the next several hundred years, the Humber became a heavily populated and actively industrialized zone, and attachment to the river and the valley through recreation and numerous mills remained strong. The Humber is a salmon river, making it a favourite fishing spot, and was termed "one of the brightest stretches of landscape on the face of the earth" by an admirer in $1894 .{ }^{12}$ Early photographs provide an idea of the scope of recreational attachment the river engendered among the local people and visitors "from the city" (fig. 1).

Instead of celebrating, or involving, the collective memories and meanings of the last two hundred years of habitation, the reinterpreted site now retells the story of Étienne Brûlé, who is
LEY, David. "Modernism. Postmodernism, and Struggle for Place." In. ACNEW, John and James DUNCAN (eds.). The Power of Place: Bringing Together Ceographical and Sociological Imaginations. Winchester (MA): Unwin Hyman, 1989, p. 51. 12

FILEY, Michael. A Toronto Album: Climpses of the City of Toronto. Toronto: Dundurn, 2001, p. 49. 


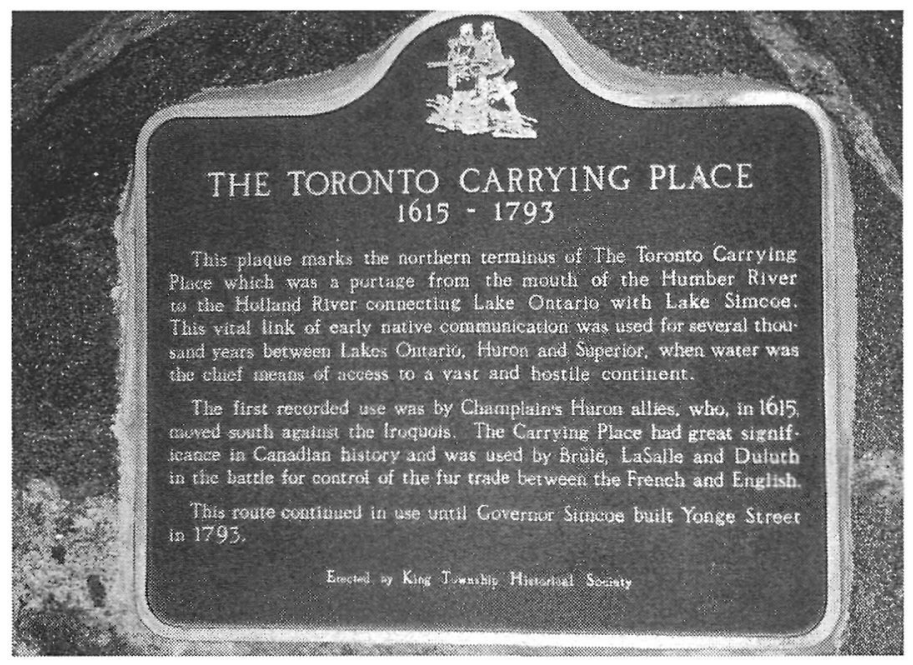

Toronto Carrying Place commemorative plaque. Photo: Diane Boyer 


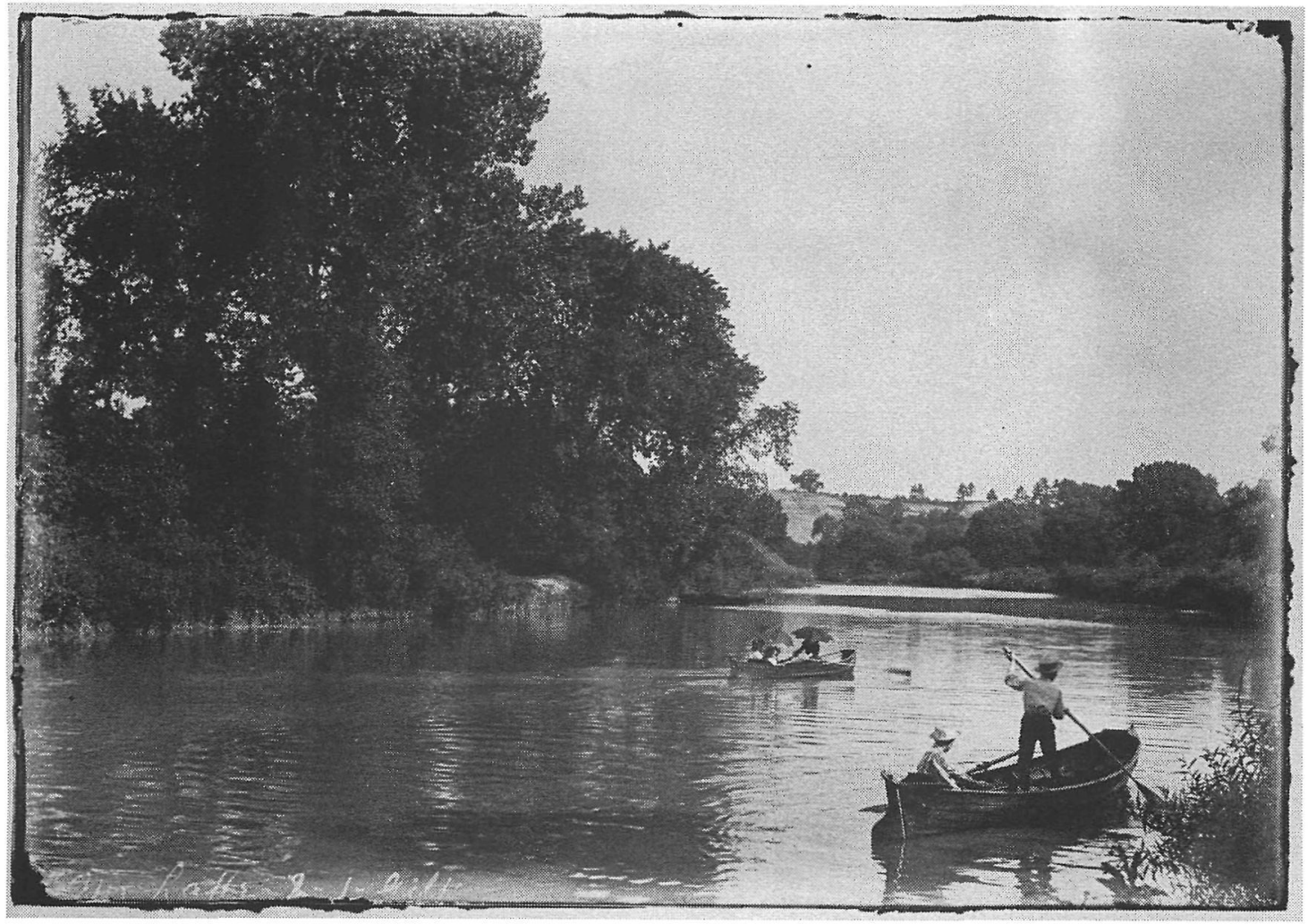

\section{Figure 1}

Recreational boating

on the Humber River, 1891.

City of Toronto Archives, Fonds 1128,

Series 379, Item 1202. 
13

LEY, "Modernism. Post-modernism, and Struggle for Place," op. cit., p. 54. credited with being "the first White man to see Lake Ontario." Brûlé also has a nearby park, school, and street named after him, and a large granite monument sits on the hillside where he purportedly made his "discovery." Recent scholarship suggesting that Brûlé's passage actually took him to Lake Erie, not Lake Ontario, has not been introduced to this myth-making machine. The new interpretation also inexplicably includes a series of plaques commemorating the travels of Samuel de Champlain, who never even visited the Toronto Carrying Place or the Humber district.

Some of this could be acceptable as local folklore, or even storybook "fakelore," but its inadequacy is so glaring-both in questionable scholarship and supreme ethno-centricity-that it is actually harmful to an evolving community that needs to reestablish its identity, strengthen local pride, and emotionally reconnect to the river and its environment. Since the 1950s the Junction-Lambton neighbourhoods surrounding the Humber site have seen declining economic activity and the destruction of several cultural landmarks. The neighbourhood population has also been augmented in the last twenty years by the arrival of many new immigrant groups, but has seen little success, yet, in composing an "integrating myth" social cohesion.

Throughout the district there is a deep underlying theme of traveling, trade, and transportation. The nearby commercial district, named the "Junction" for its location at the intersection of two railroads entering the city from the north and the west, was a prosperous multiethnic community until the 1960s, with large Black, Jewish, and Irish populations descended from waves of immigration throughout the 1800 s and into the $20^{\text {th }}$ century. Many of these residents historically found employment on the railroad or in the huge abattoirs situated on the north side of the tracks, which employed 10,000 people in their heyday.

The strong currents of constant movement and migration-down the Trail, on the river, along the Dundas Highway, or on the railroads-were slowed by an ongoing series of changes and redirections in transportation, especially after the construction of the Bloor subway and the Gardiner Expressway in the 1950s. Dundas 
Street, once a stage coach route and main thoroughfare across the top part of the city, lost its link to railroad passengers when the historic West Toronto train station, built in 1876, was demolished in 1972 to much local anguish. The once thriving commercial district which boasted furriers, jewellers, custom tailors, and large department stores quickly atrophied, and by the 1980s the neighbourhood had the highest commercial storefront vacancy rate in the city of Toronto, and was touted as the speculative location for a proposed "red light district." The abattoirs closed completely in the 1990s, eliminating thousands of local jobs, and surviving public buildings, such as the limestone Centennial post office built in 1967 , were repurposed for non-local use. (The post office is now a halfway house for fifty federal penitentiary parolees. $)^{14}$

The construction of the Gardiner Expressway in 1956 made the parks and wetlands below Bloor Street less attractive for recreational use, and sites like Rousseaux's landing ${ }^{15}$ were basically abandoned by local users. Still navigable by boat under the six-lane Gardiner bridges over the Humber, the area is only barely traversable by foot, and recent work in paving walkways has improved pedestrianization only marginally. The old bridge across the Humber at Dundas Street was also demolished, and the "spur" of the old road, which now ends in a dead end at the river, was renamed old Dundas Street. The "new" Dundas Street carries cars and intrepid pedestrians across a 1960s aqueduct-like bridge, elevated over the valley neighbourhoods. The historic Lambton Inn, the only remaining building from the riverside hamlet of Cooper's Mill, now perches on the hill in the shadow of towering new developments. ${ }^{16}$

The Humber River has a latently dangerous personality that captivates everyone with any memory of traveling or living near it. Over the years, numerous unfortunates have drowned in it, usually during the spring floods, and the river's winter ice jams are annual "tourist" draws. Its occasionally catastrophic primordial power is locally remembered by two blue wavy lines-the high water mark from the Hurricane Hazel flood in 1954-painted six metres overhead on the pillars of the Bloor Viaduct. More than 60 houses were washed away down the Humber in that event, and 35 valley residents lost their lives. Further building was banned on the flood plain after the hurricane, and extensive parkland is
14

The 1967 edifice replaced the original -and very impressive-19 1 th $^{\text {t century, }}$ three-storey customs house which was demolished to make way for a parking lot servicing the Bank of Montreal.

15

This is what I call it; it has no name yet.

16

The village had been renamed "Lambton Mills" in 1838 following a visit by John Lambton, Earl of Durham, a British aristocrat, but has recently reclaimed its heritage as Cooper's Mill, named for the family whose sawmill was located there. 
17

<http://murmurtoronto.ca/index. php>.

18

LIU, James H. and Denis HILTON. "How the Past Weighs on the Present: Social Representations of History and their Role in Identity Politics." British Journal of Social Psychology, vol. 44, 2005, p. 549.

19

RELPH, 1976, op cit., p. 40. maintained along both sides of the river. In better weather, the system of parks provides many kilometres of contemplative walking and bicycle trails.

\section{Activating local history}

Little or none of this history will be expressed in the new cursory interpretation in the Valley, but utilizing an ecomuseum model could activate the creative potential latent in the area. Pieces of a nascent ecomuseum are already in place through oral history collections by artists' cooperatives such as [murmur], ${ }^{17}$ while the local West Toronto Junction Historical Society holds an extensive archival collection with a remarkable photographic record of the area.These existing attempts to record local history speak evocatively to the personal, emotional involvement that quickly surfaces when people are asked to tell their own stories, compose their own activities, and write their own histories. The oral histories already collected, tremendously evocative "intangible objects" in their own right, prepare an excellent groundwork for further work in heritage appropriation. Local residents describe the buildings they occupied, the businesses they ran, and the people they loved and married. It's a simple interpretive strategy, and very compelling, making an indelible affective link to the district available to anyone who listens.

The affective link is key to the kind of cultural commotion that can activate community imagination and enable "core lessons from history to structure people's responses to new challenges." ${ }^{\text {"18 }}$ Historical narratives, their content and the way they are told, can either strengthen or disable a community's cultural identity.A strong base of historical narratives bonds local identity, allowing communities to mobilize collective memories to meet developing crises or resolve internal conflicts. Fomenting cultural commotion can also provide an access point to the compensatory effects available from a feeling of belonging. Urban geographer Edward Relph describes the sense of "home" as a powerful desire for secure and safe places and a "profound form of attachment to a particular setting, a particular environment, in comparison with which all other associations with places have only limited significance." ${ }^{m 9}$ Deprived of these sensations of home, he says, people exhibit "emotional 
responses that could properly be described as grief and [...] a sense of painful loss [and] helplessness."20

Without a sense of belonging, or a "historical charter" of their own, communities like Lambton-Junction are whittled away in a chaotic realm of placelessness through the erosion of distinctive experience and a gradual deadening of interpersonal relations. Recent developments will soon put this notion to the test as the new metropolitan transit strategy-The Big Move-races forward with plans to run 400 non-stop high-speed diesel trains daily through this neighbourhood, threatening to crush the liveability of its residential districts. Here is where active heritage reappropriation-relevant, meaningful cultural commotion-could help mobilize residents and defend neighbourhood interests against wider regional demands.

\section{The ecomuseum's "pearls of significance"}

In earlier work, I have postulated the notion of a museum as a generative "point of collision" between mythic and historic world views. The ecomuseum concept provides multiple opportunities for such points of contact and cultural commotion. An ecomuseum has been described by Peter Davis as the connective thread that holds together a neighbourhood's distinctive sites and landmarks like "pearls of special significance" on the string of a necklace. ${ }^{21}$ The seemingly fragmented ecomuseum is held together by a web of human intentions and relationships in a socially produced space such as the "heterotopias" that Michel Foucault describes when he writes:

We do not live in a kind of void, inside of which we could place individuals and things [...] we live inside a set of relations that delineates sites which are irreducible to one another [...] The heterotopia is capable of juxtaposing in a single real place several spaces, several sites that are in themselves incompatible [...] they have a function in relation to all the space that remains. ${ }^{22}$

In the Humber Valley, inter-related heterotopic points of cultural commotion are evident. As an example, the bike path along the western shore of the Humber River is home to an unusual
20

Id. p. 40.

21

DAVIS, Peter. "Places, Cultural Touchstones and the Ecomuseum." In. CORSANE, Gerard (ed.). Heritage, Museums and Galleries: An Introductory Reader. London: Routledge, 2005. p. 374.

22

FOUCAULT, Michel. "Of other spaces." Diacritics, spring 1986, p. 23. 
Figure 2 (Top)

Spaceship by the Humber. Photo: Diane Boyer

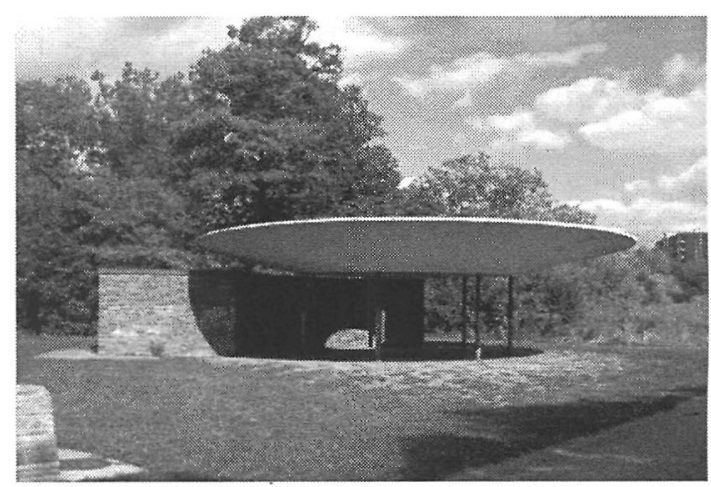

Figure 4 (Left)

The Lambton House was a

stagecoach stop in the 1800s.

Photo: Courtesy of Heritage York

Figure 3 (Below)

Lambton House Inn.

Photo: Diane Boyer

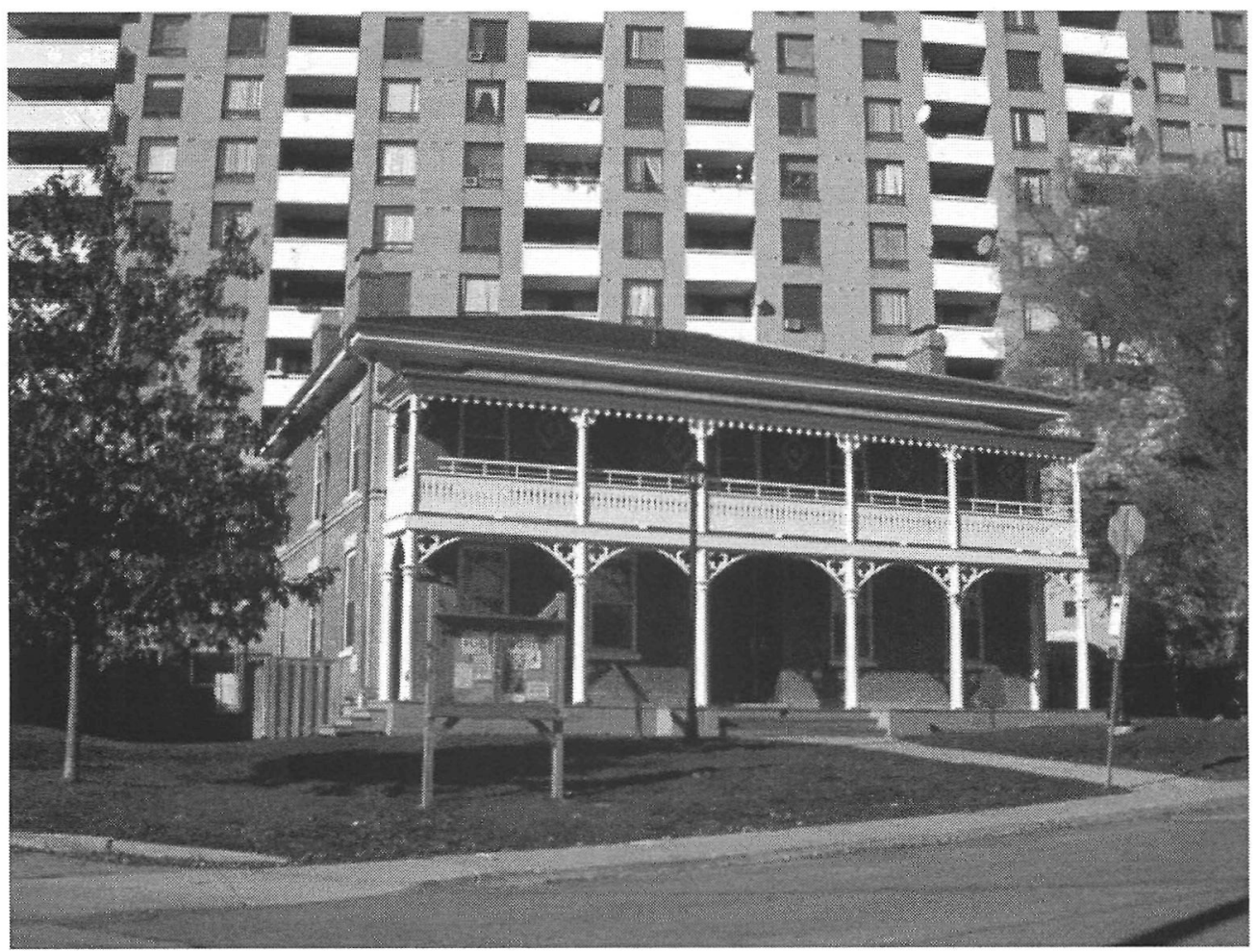


building which locals call The Spaceship or the Flying Saucer (fig. 2).This extraordinary 1960s relic, a public washroom building, now decommissioned and heavily "graffittied," sprouts like an exuberant mushroom out of the landscape. Near it, on a newly groomed hill, is Étienne Brûlé's heavyset granite monument.

The special weirdness of the place is generated by the interrelational bouncing through the centuries that these two artefacts occasion, even though they are contemporaneous to one another. Brûlé's vaunted, and likely imaginary, "first sighting of Lake Ontario" is now obscured by overgrown trees, which hide the view (though not the crosswind) of the massive collecting tanks of the Humber Wastewater Treatment facility. These three 1960s sites strung together, two of them the hygienic necessity of human habitation, and the third a ponderous ode to historic myth, are a triad of special sites for the locality, and among the many vernacular cultural touchstones strung along the banks of the river. They work together to form one possible thread of the ecomuseum.

On the other shore, by the remnant of Old Dundas Street, is another collision between place and placelessness. The Lambton House Inn (figs. 3-4), built in 1847, survived Hurricane Hazel, the demolition of both the town it served and the old Dundas Street bridge that ferried its customers. The Inn's new challenge is to maintain its identity in a nameless environment. Several years ago a developer demolished the back half of the historic structure and erected an apartment building that overshadows the old inn with a cliffside of uniform balconies.

Although it is a restored heritage site, and a favourite destination for Doors Open Toronto visitors, the Lambton Inn regularly hosts a spectacularly well-attended pub night in a fashion which is probably not very different from the tavern's function in the $19^{\text {th }}$ century. Once a month, and for special occasions, the unrestored first floor is packed with imbibers, with one room, by natural selection, devoted entirely to single men, while couples, single women, and families congregate in the larger room to the side. Besides alcohol, there is only one item on the menu-roast beef sandwiches-and only one form of entertainment on the stage-local. Pub nights maintain local involvement with the 
23

CORSANE, Gerard. Cited in DAVIS, Ecomuseums: A Sense of Place, op. cit., p. 68.

24

See POULOT, "Identity as Selfdiscovery...," op. cit., p. 70. historic building, which is in turn dependent on their support for its very survival, a pure example of ecomuseum reciprocal philosophy.

So what could make each of these sites the "pearls" on the ecomuseum necklace? An ecomuseum has sometimes been described as a series of antennae, rather than a static site. The ecomuseum's geographic landmarks and cultural touchstones act as transmitting towers scattered throughout a territory, maintaining a kind of canopy of filtered messages, greetings, stories, and news. The ecomuseum organizes a network of museum-like activities that foster local identity: historical and contemporary research, the collection of stories, public displays and education, ${ }^{23}$ and, at a site like the Humber River, active recreation such as canoeing and hiking. In other words, the multiple sites making up the ecomuseum are connected-and the ecomuseum is erected-by the gathering of meanings and activities in a collectively imagined world. The ecomuseum has both a real world and a virtual body, whose avatars change or interact as local history constantly develops. Always situated in the present, the ecomuseum is nonetheless a steady accumulation of all possible pasts as well.

The ecomuseum model celebrates both antique artefacts and modern-day manufactures, but object collection is not its primary function. The ordinary item that Veillard discussed-his "valueless object"-holds an equal position in the ecomuseum as does the historical artefact-each tells its own piece of the unifying story. In its broadest sense, the ecomuseum might contain every single thing within a demarcated territory, inciting some critics to term the ecomuseum a "vast junk museum.".24 The point of an ecomuseum is not to collect objects to exhibit, but to collect meanings to share and own.

Where actual objects are "collected," ecomuseum philosophy holds that they be left in situ whenever possible so that their function is evident, and they can be observed and interpreted in their own context, not simply displayed as curiosities in a case. In the ecomuseum, a community will create and study its own art and artefact, preserve its own history, and describe itself in its own words. The ecomuseum "mirror" that Rivière proposed can generate a heritage interpretation that is not stuck in time, 
but relevant and appropriate to a living and dynamic community that reasserts its own sense of place.

\section{Epilogue}

Returning to the river's edge in December 2009 to examine the shoreline after the foliage was gone, I found something that had been obscured during the summer. In both directions, as far as I could see along the river's edge, a marching line of wooden posts had been driven into the ground. Each one was the diameter of a telephone pole, and most were rotted off a few centimetres above the sand (fig. 5). They looked to have been set in place many decades ago. I realized that there must have been some kind of structure built along the river's edge-a boardwalk or a long dock-a sizeable portion of which must have been obliterated by the construction of the Gardiner Expressway. When Rousseaux's now-peeling plaque had been set in place, I reasoned, it would have stood in a park-like clearing where visitors could launch their boats or stroll along a boardwalk.

Searching online later for archival images, I came across a postcard depicting boaters on the river (fig. 6). Behind the flotilla was a group of spectators clearly standing on a large dock, or boardwalk at the river's edge. I reflected on the picture I'd taken one hundred years later of the rotted off posts by the river, and felt a deep sadness at the abandonment of pastime they seemed to represent. Some things can't be resurrected or replaced, but the river continues to flow by, and since I believe deep structures always prevail, the valley's ecomuseum is inevitable, and even now coming into being. 


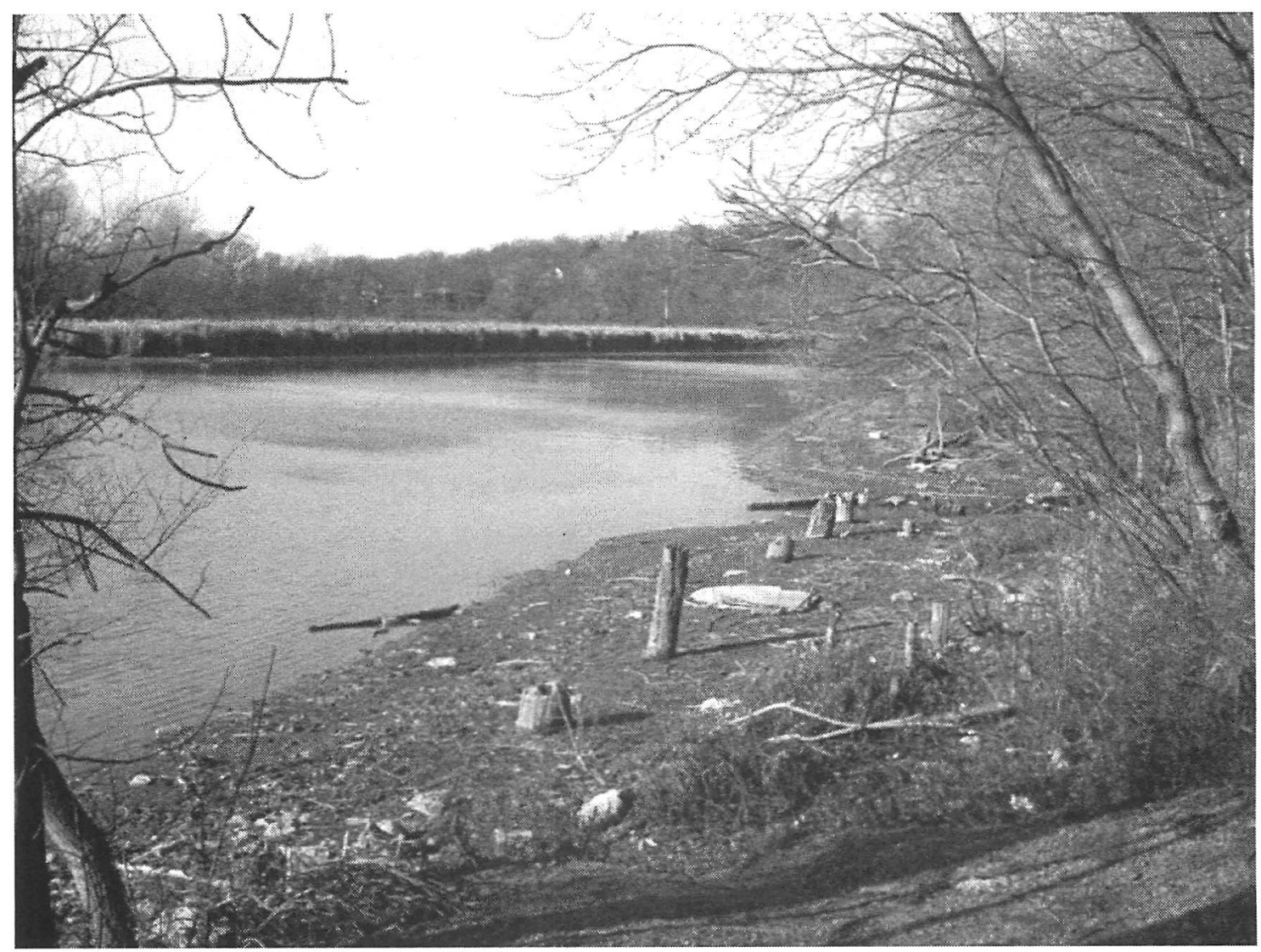

Figure 5

Rotted posts of the old pier.

Photo: Diane Boyer 


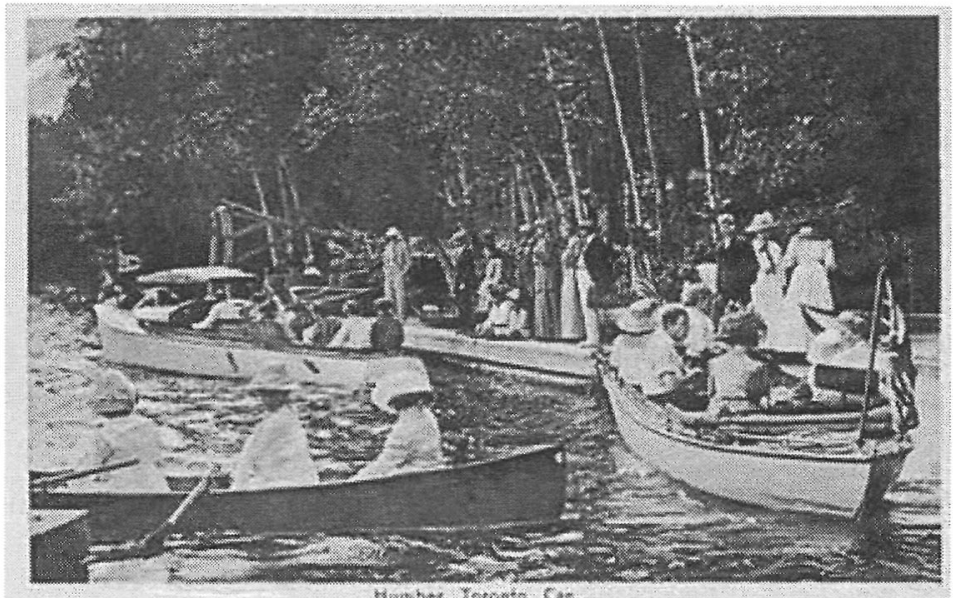

Figure 6

Spectators on the riverside dock, c. 1913.

Retrieved from

http://chuckmanothercollection.blogspot.com/ 
Traduit par: Entre impact culturel et écomusée: Philippe le Toronto Carrying Place Lagrange

En se basant sur le modèle de l'écomusée, cet article souhaite faire la démonstration de la diversité des interprétations du Toronto Carrying Place. La révélation du lien complexe entre l'architecture et le paysage naturel qui émerge lorsque de nouvelles interventions sont pratiquées dans un lieu a incité l'auteure à faire appel au concept d' « impact culturel "qui prend en compte la nature des souvenirs et la réappropriation de l'histoire d'un lieu par un groupe. Ce concept d' "impact culturel " serait en fait une méthode d'interprétation du monde contemporain inspirée par la vision holistique de Georges-Henri Rivière. Puisque ces deux conceptions partagent une même philosophie et plusieurs idéaux, l'impact culturel chercherait sa validation dans le mouvement écomuséal holistique afin d'appuyer les nouvelles interprétations du patrimoine culturel, mieux adaptées aux populations urbaines contemporaines. Ces nouvelles interprétations serviraient à améliorer la relation parfois ambivalente que ces groupes entretiennent avec les récits du passé des lieux qu'ils ont choisi d'habiter.

L'article utilise comme cadre de référence les deux "composantes fondamentales" du site: la vallée de la rivière Humber, créé par la nature et la vieille piste du Toronto Carrying Place, aménagée par l'homme. La piste (et son tracé initial) qui n'existe pratiquement plus aujourd'hui, a un passé bien documenté et son empreinte persiste toujours dans l'inconscient collectif. L'activité humaine quotidienne dans la piste et la vallée génère l'élaboration progressive d'un "sentiment d'appartenance" chez les usagers. La piste, la rivière, les chemins longeant les autoroutes ou les chemins de fer croisant et reliant le site et ses environs à l'état actuel de la vallée 
de la rivière Humber étaient jadis une seule et même route qui servait à faire du commerce. Cette route est aujourd'hui transformée par des résidences et des centres commerciaux, mais malgré ces transformations, l'auteure soutient que l'impact culturel s'y manifesterait toujours, grâce à des énergies sous-jacentes qui seraient toujours présentes dans le lieu et seraient exploitées par les résidents actuels qui cherchent à se l'approprier.

En plus du concept d'écomusée ou du «...un miroir à travers lequel la population se voit et découvre sa propre identité", les travaux d'Edward Relph et d'autres géographes radicaux de l'Université de Toronto orientent aussi cette réflexion. Un bref aperçu des origines de l'écomusée et de son approche interprétative sont appliquées à la lecture de la vallée de la rivière Humber afin de comprendre si ce modèle peut permettre une nouvelle interprétation du patrimoine culturel du site tout en racontant son histoire. Même si la géographie de ce paysage a déjà été interprétée de façon plus ou moins directe par des activités industrielles et récréatives diverses, l'auteure cherche à découvrir comment les gens qui l'habitent interprètent le lieu et son histoire en tenant compte des nouvelles applications de la géographie modifiable. Le fait, par exemple, que la nouvelle population soit multilingue (exception faite du français ou de l'anglais) et qu'elle maintienne un lien affectif étroit avec d'autres endroits ailleurs dans le monde, l'amène à s'interroger sur les motifs qui favoriseraient les gens à développer un sentiment d'appartenance ou un lien mutuel lors de leur passage au Toronto Carrying Place. L'interprétation actuelle du site serait appelée à être modifiée au fil du temps si l'on se fie aux idées concernant l'espace et la philosophie axée sur le lieu de la géographie postmoderne. En fait, les concepts et la nature fragmentaire, éphémère et discontinue des paysages habités contemporains, pourraient révéler les étapes de transformation des interprétations de ces sites patrimoniaux, parce que selon l'auteure, ces sites seraient des loci où la géographie humaine et les histoires populaires entrent en résonnance et s'augmentent mutuellement. 